Vol. 2, No. 1, 2021

Ivan Pasnak, Artur Renkas

Lviv State University of Life Safety

35, Kleparivska Str., Lviv, 79000, Ukraine

(C) Pasnak I., Renkas A., 2021

https://doi.org/10.23939/tt2021.01.013

\title{
JUSTIFICATION OF TRAFFIC SIGNALING MODES AT INTERSECTIONS CONSIDERING THE PRIORITY OF PUBLIC TRANSPORT
}

\begin{abstract}
Summary. With the growth of the road transport fleet and increase of urban agglomerations, the availability of private transport on the streets of cities with a population over 500 thousand inhabitants is quite noticeable. The previously developed general plans of such settlements, in modern realities, are impossible to implement both from a financial point of view and in terms of the urban space organization. Given the impossibility of meeting the needs of private car users, public transport comes first in the priorities of urban mobility. Problematic areas of the road network in many western Ukrainian cities are those that are densely populated. In such cases, it is not always possible to redesign elements of street sections or intersections, so the traffic management improvement is limited to organizational measures. Among them, the most popular and least expensive are the change the modes of light control at intersections. Considering modern opportunities, technical means and scientific achievements, the capacity of signalized intersections is high. The same applies to the principles of giving priority to public transport over time (at signalized intersections). At present, a significant number of methods and algorithms for detecting and heading the movement of public transport at traffic lights have been developed, however, the criteria for the application of each of them are not fully understood. As a result of the conducted research, the change of queues in front of stop-lines at intersections depending on types of signalization is defined. The results showed that the existing type of control creates significant traffic delays on secondary streets. As a result, it is proposed to use adaptive control, which provides for the adjustment of the traffic light cycle in the presence of tram traffic. Using traffic simulation tools, it became possible to choose different modes of traffic lights control at intersections, which can provide public transport priority, while minimizing the negative impact on the adjacent elements of the road network.
\end{abstract}

Keywords: traffic management, public transport priority, traffic lights control, queues on intersections, traffic modeling.

\section{INTRODUCTION}

Urban traffic management is a difficult task for both engineers and scientists. At this time, the number of cars on the streets and roads of large and very large cities of Ukraine is constantly growing. This is due to both the ability of the population to improve their living standards, which is characterized by multitasking and the inability of social and transport infrastructure to meet the needs of citizens [1-2].

Due to the increase in vehicles and their improvement, the street space and traffic management schemes in general need to be improved.

Providing traffic scheme organization includes installation of traffic lights and changing their modes, traffic canalization, and installation of new road signs. These measures are aimed at reducing congestion and increasing the capacity of intersections. 
Due to the limited conditions in the city with lots of historic buildings, measures to improve traffic management schemes sometimes are limited. The preference in traffic, in this case, is given to public transport to increase the speed of communication.

During the increase of motorization level, a large number of the city's population should prefer public transport, however, its performance is far from those that would attract people to make their choice in favor of trams or buses. To this end, it is necessary to implement measures to improve the speed and regularity of public transport, giving priority to its control.

As you know, no traffic restriction eliminates its needs, so when giving priority to public transport we should take into account the interests of other road users. To this end, extensive research is being conducted and the process of finding compromise solutions is underway in order not to give priority to one group of movement to create significant discomfort for others.

\section{RESEARCH STATEMENT}

It is known that to ensure priority movement at signalized intersections, there are many methods and techniques that cover two types of those intersections from the point of their control: isolated, and those that are combined with a system of coordinated control [3].

Ensuring priority over time is divided into two types - passive, which uses fixed-time control algorithms, and active, which is implemented by adaptive control [4].

Multi-program fixed-time control is used to adapt the parameters of traffic lights to fluctuations in daily traffic. This reduces delays for all threads [5]. Such decisions do not provide an advantage in the movement of public transport over other road users, and therefore are an auxiliary method of ensuring priority at intersections.

At signalized intersections, the increase of main time duration for priority flows is usually applied in the absence of public transport in the following phases. This helps to increase the following parameters: the capacity of this direction, the probability of passing on the permitted traffic light signal, and the speed of all vehicles. The only disadvantage of this method is the inefficiency of the control regime for conflicting areas.

All methods of active priority are implemented by detecting public transport at the entrance to the intersection, after which there are appropriate changes in the modes of traffic lights. This ensures the passage of the intersection without significant delays [3].

The presence of transport can be fixed in contact and non-contact way. Contactless is possible with both local radio-based systems and central systems using GPS (detection accuracy up to 10-20 m).

The most common of the adaptive algorithms that provide priority is the continuation of the main time [3]. This algorithm is implemented at the time of the appearance of the public transport unit on the approaches to the intersection during the end of the green signal. In this case, the duration of the main time, where traffic is allowed, is extended for a certain period of time and thus ensures the passage of the intersection without delay.

To ensure the priority at the time of public transport unit arrival to the intersection during the period of the forbidden signal, the algorithm of its early termination is used [3]. The implementation of such an algorithm is impossible in the presence of pedestrian traffic in the phase that must be completed ahead of schedule.

Another algorithm, from the standpoint of ensuring absolute priority, is the call of a special phase, the occurrence of which is possible at any time of the control cycle [5]. To ensure the effective control of traffic lights at the intersection when implementing this algorithm, the "compensation" method is used [6]: after the public transport unit has received priority passage using a special phase, time costs of non-priority directions are compensated by continuing the main green light in their directions for the calculated period.

The disadvantage of this algorithm is that with a significant intensity of public transport arrival to the intersection, ensuring priority creates an unstable control mode for secondary flows. Moreover, the conflicting directions can be in conditions of almost constant action of the restrictive signal. In this regard, 
the author [7] stated that the interval between buses should not be less than 2.5 minutes. In addition, the absolute priority for some route vehicles may create obstacles for others.

Given all the above, the study of traffic flow parameters changes in different ways of giving priority to public transport is a topical issue today. First of all, such studies are relevant for those sections of the road network where the change of traffic scheme can be implemented only by organizational measures (prohibition of maneuvers, change of lane, change of traffic lights, etc). These areas are characterized by dense historic buildings, so a full-fledged change in the traffic pattern together with the geometric parameters of the intersection, depending on the traffic flow composition, as studied in [8], is impossible. In [9], the problem of changing the parameters of traffic light regulation to prioritize public transport movement is considered in part.

The main objectives of the research are:

- the definition of eligible types of traffic light control at intersections that provide public transport priority;

- the study of traffic indicators change at intersections in various traffic lights signaling modes through simulation modeling;

- justification of signal control modes at intersections to gain public transport priority by the criterion of minimum delays on secondary directions

\section{CHARACTERISTICS OF RESEARCH OBJECTS AND METHODS OF THEIR CONDUCTION}

The object of study is a section of the city street, which belongs to the arterials of district importance. The main feature that determines the mode of movement on it is the presence of a tram, which is followed by one route with an interval of 5-7 minutes. Combined pavement - slabs for tram tracks and cobblestones. There are 3 signalized intersections along the street (Fig. 1).

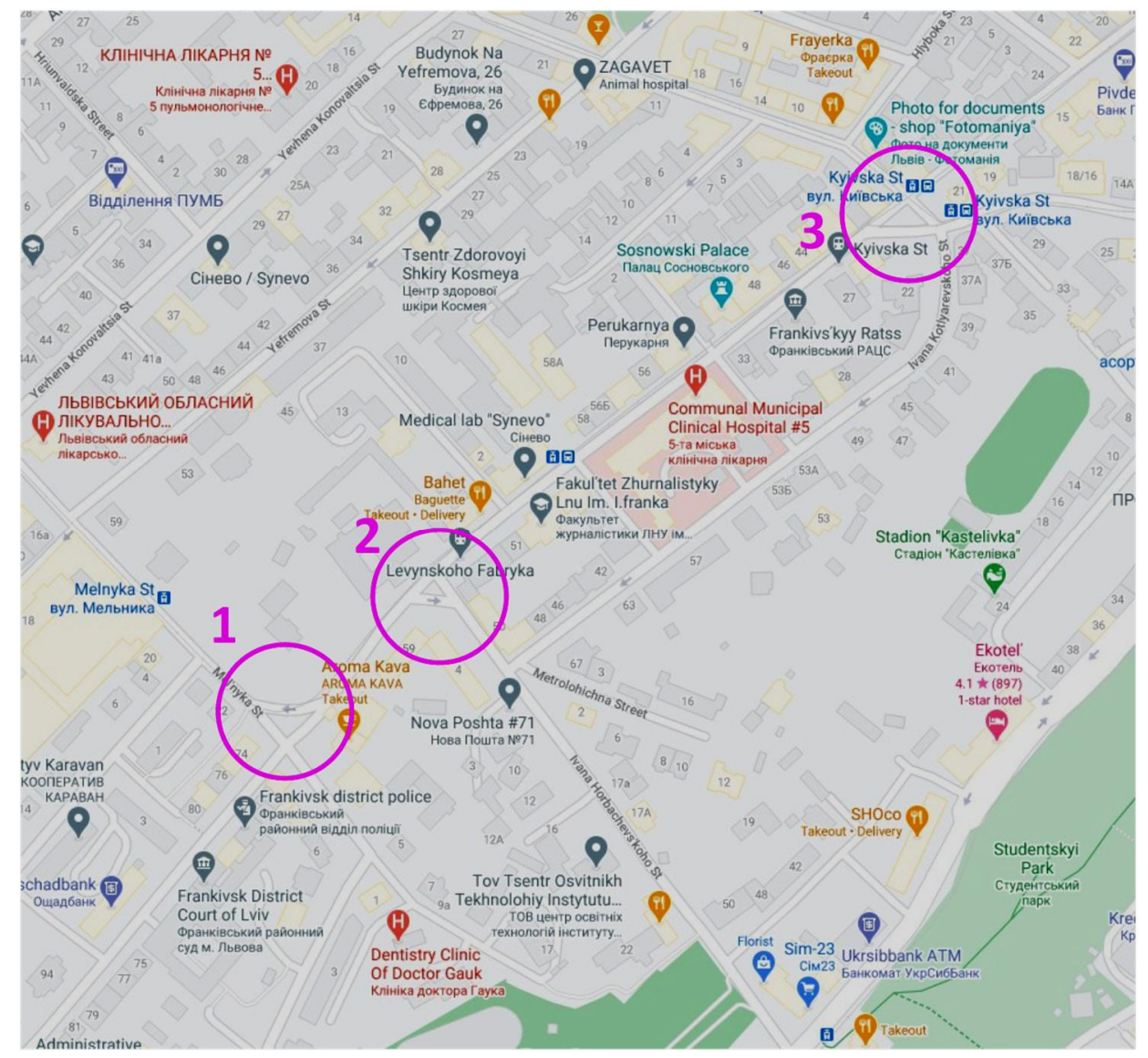

Fig. 1. Scheme of observed intersections 
For further research, plans of intersections are given (Tables 1-3) with directions of movement in Latin letters, which will be the basis for compiling a matrix of traffic flow intensities in passenger car units per hour.

Table 1

Traffic flow on intersection No. 1

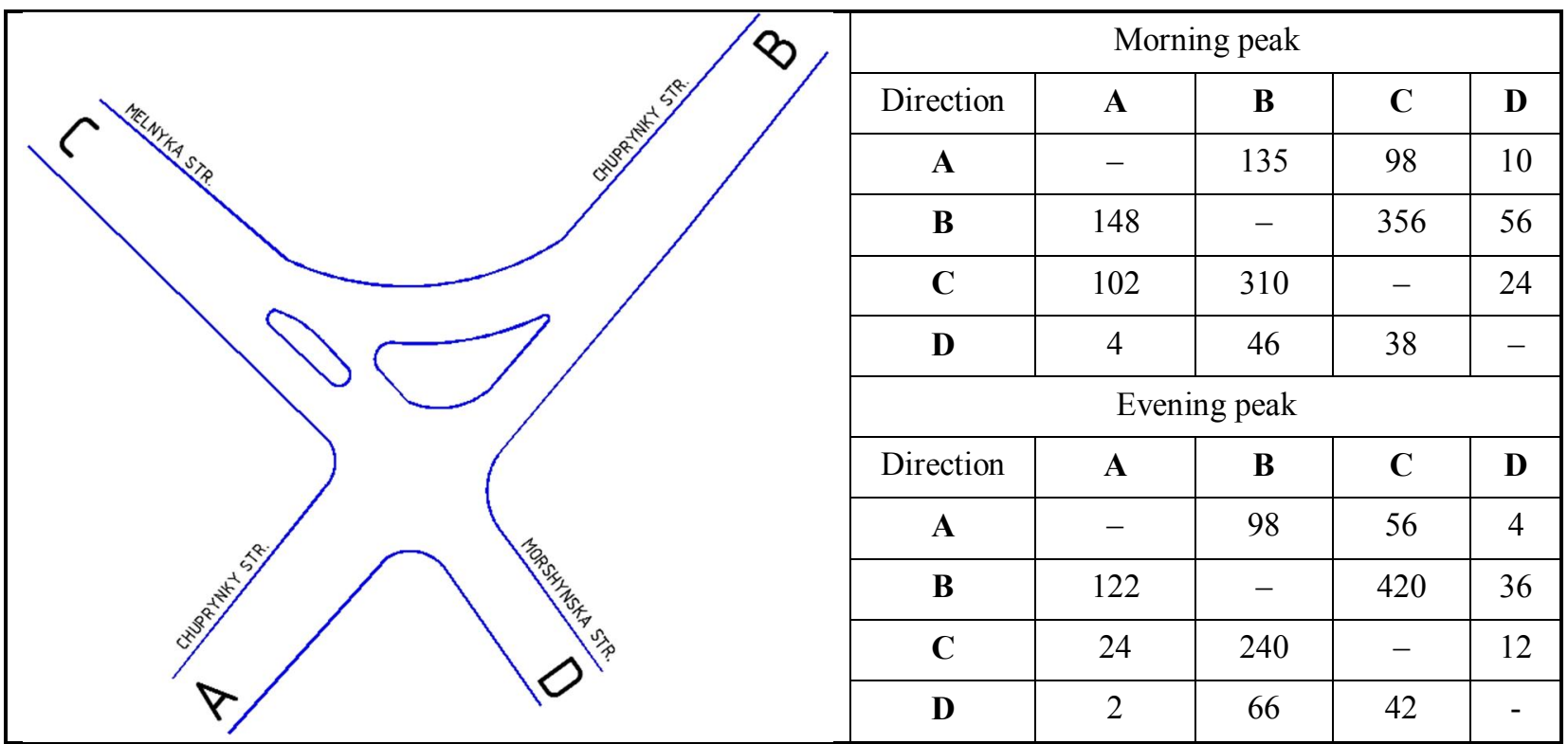

Traffic flow through this intersection at different peak periods of the day is different. The most massive are flows B-C to the right in the morning peak, as well as traffic flows that move in the evening from the opposite direction.

Table 2

Traffic flow on intersection No. 2

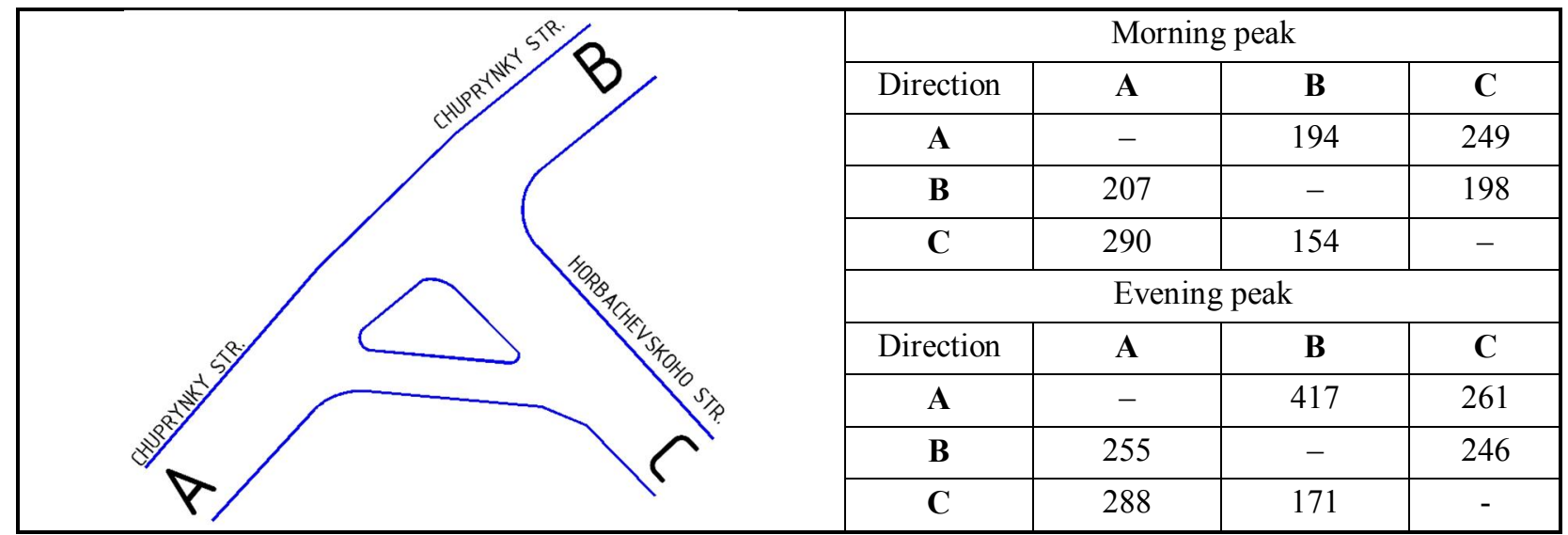

At this intersection, dominative flows are observed from approach A in the direction of the center (B) in the morning peak and vice versa in the evening. It is also worth noting the mass flow of traffic, which makes a left turn in the direction of B-C.

The results of observations indicate that despite the significant visual load by public transport, its share in the total flow is less than $10 \%$. 
Traffic flow on intersection No. 3

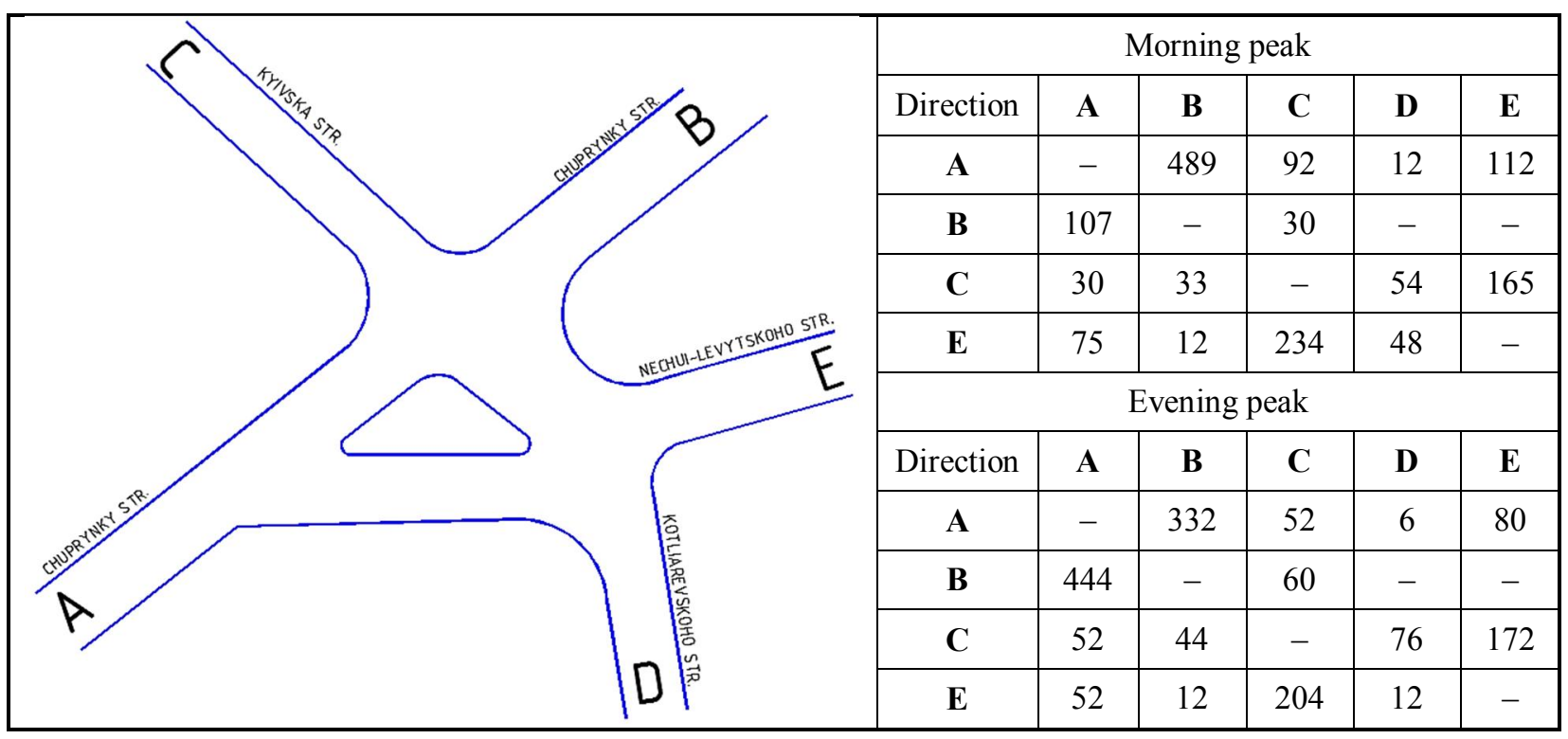

At this intersection, the dominant directions are the main ones - A-B and E-C. In the evening, there is an increase in traffic flow from approach $\mathrm{C}$.

Data on the intensity of traffic flows in the directions are input both for the calculation of the basic system of traffic lights at intersections and in the process of creating simulation models.

The main method of researching traffic, at this time, is simulation. With the help of specialized software, it becomes possible to assess the existing traffic conditions on the elements of the road network and to analyze the proposed measures to manage traffic flows. The most popular traffic simulation software products are Corsim, Aimsum, Paramics, Integration, and Sumo [10-14]. The modeling interface in such environments is different and often requires knowledge of programming languages. A large number of studies are based on research conducted in the Vissim software, as it requires minimal time to master it and has a wide and clear functionality [15]. In this work, the research is conducted in Vissim, because it is best suited for the interpretation and further research.

\section{MAIN PART}

To study the change of traffic signaling modes efficiency, the duration of traffic light cycles at intersections was calculated in accordance with the available flows and adjusted saturation. Fixed-time traffic light modes are also the basis for the introduction of adaptive control.

Phase crossings and cyclograms of traffic lights at intersections are shown in Fig. 2-4. The main input data for the calculation is traffic flow intensity by directions, its distribution, intersection geometric parameters, road surface condition, slopes, and so on. The calculation was made taking into account the needs of pedestrians and providing sufficient time for crossing the roadway.

The recalculation of fixed-time traffic light cycles for all signalized intersections indicates that in the absence of public transport prioritization, in the base, cycle duration variates from 28 to 34s. Adaptive control is implemented by special algorithms, as there is no need to constantly extend the duration of the control phases. For this purpose, it is possible to use available detectors of tram cars approach. The duration required for the tram to travel its length is $6-8 \mathrm{~s}$, for calculations selected $7 \mathrm{~s}$. The results of cycles adjustment considering tram traffic are given in Table. 4. 

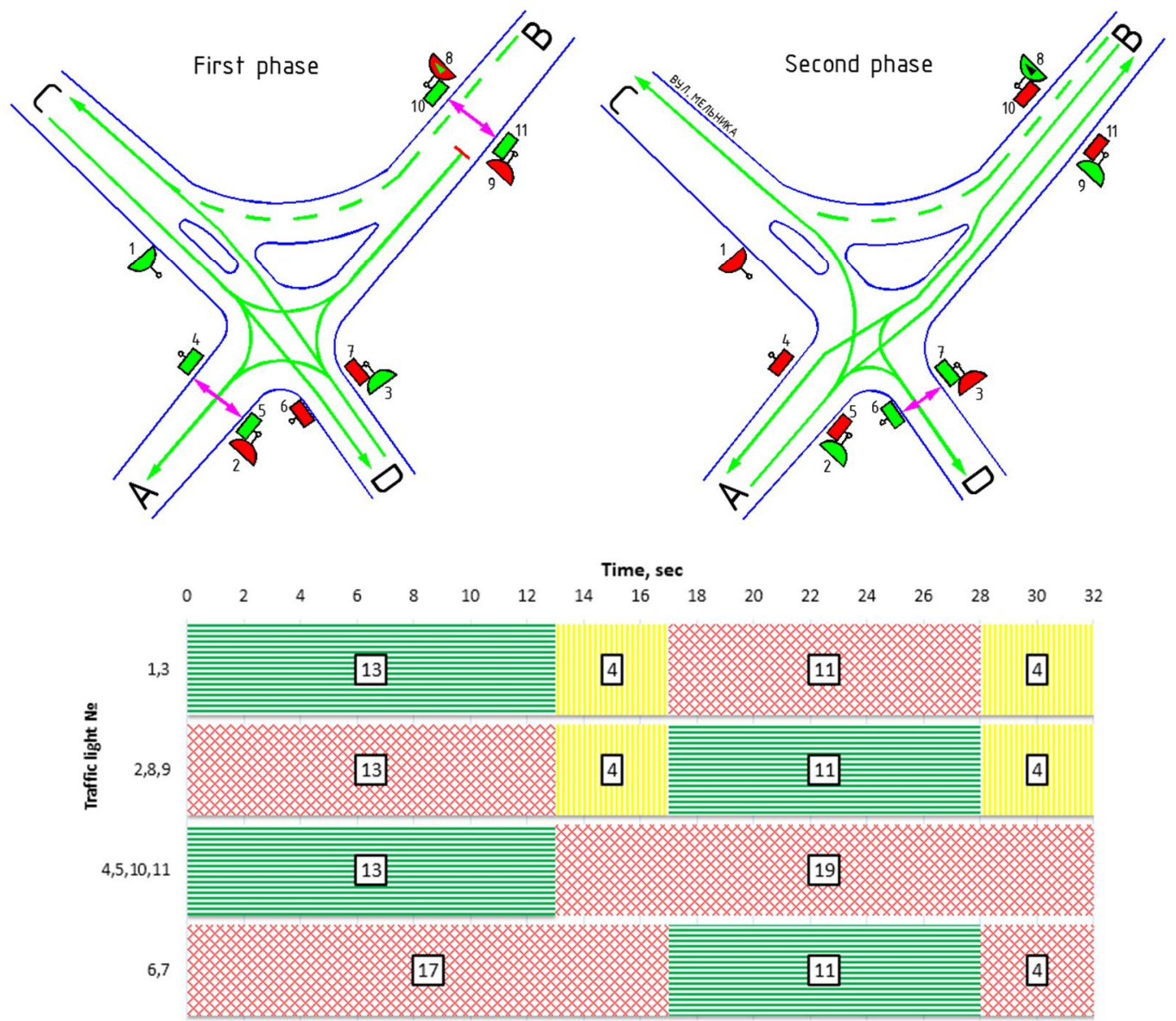

Fig. 2. Phase crossing and cyclogram of traffic light signaling mode at intersection No. 1
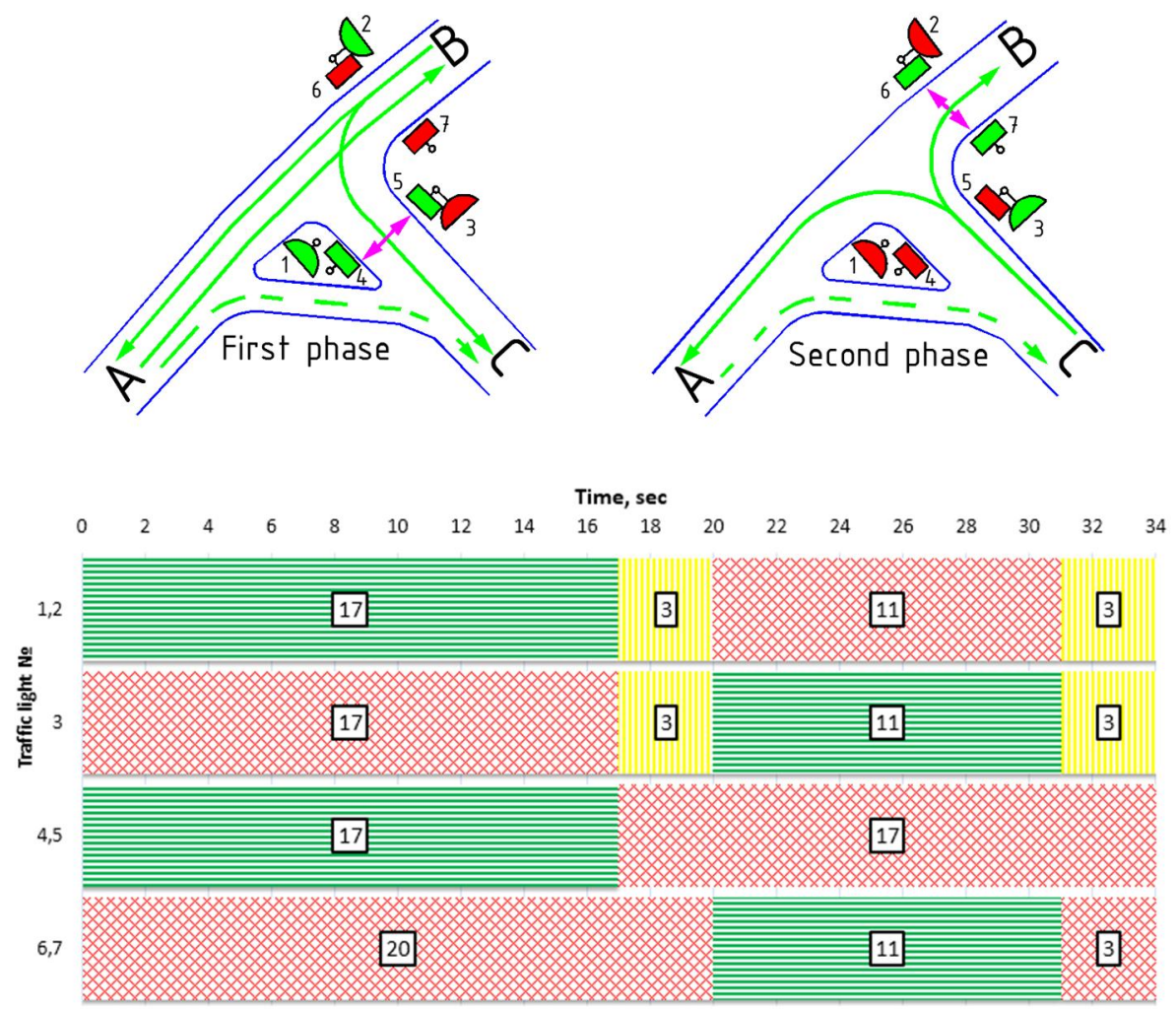

Fig. 3. Phase crossing and cyclogram of traffic light signaling mode at intersection No. 2 

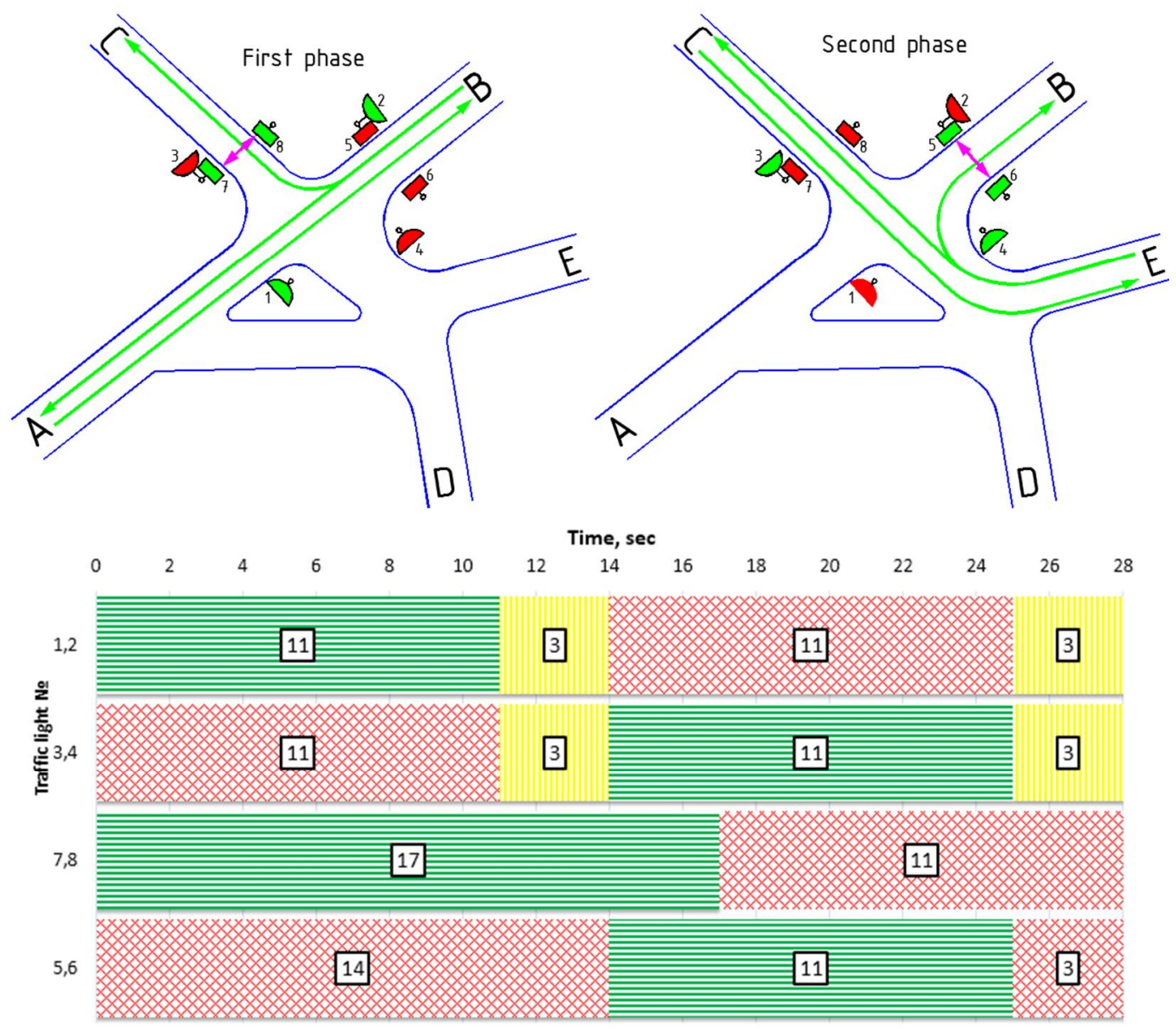

Fig. 4. Phase crossing and cyclogram of traffic light signaling mode at intersection No. 3

Table 4

\section{Calculation of corrected traffic light cycles}

\begin{tabular}{|c|c|c|c|c|c|}
\hline \multicolumn{6}{|c|}{ Intersection 1} \\
\hline \multirow{2}{*}{ Phase } & \multirow{2}{*}{ Flow, p.c.u/hour } & \multirow{2}{*}{ Correction factor } & \multicolumn{2}{|c|}{ Main time duration, sec } & \multirow{2}{*}{$\mathrm{Tc}^{*}, \mathrm{sec}$} \\
\hline & & & extra & summary & \\
\hline 1 & 1696 & \multirow{2}{*}{0.86} & 7 & 20 & \multirow{2}{*}{45} \\
\hline 2 & 1970 & & 6 & 17 & \\
\hline \multicolumn{6}{|c|}{ Intersection 2} \\
\hline \multirow{2}{*}{ Phase } & \multirow{2}{*}{ Flow, p.c.u /hour } & \multirow{2}{*}{ Correction factor } & \multicolumn{2}{|c|}{ Main time duration, sec } & \multirow{2}{*}{$\mathrm{Tc}^{*}$, sec } \\
\hline & & & extra & summary & \\
\hline 1 & 1438 & \multirow{2}{*}{1.00} & 7 & 24 & \multirow{2}{*}{48} \\
\hline 2 & 1434 & & 7 & 18 & \\
\hline \multicolumn{6}{|c|}{ Intersection 2} \\
\hline \multirow{2}{*}{ Phase } & \multirow{2}{*}{ Flow, p.c.u /hour } & \multirow{2}{*}{ Correction factor } & \multicolumn{2}{|c|}{ Main time duration, sec } & \multirow{2}{*}{$\mathrm{Tc}^{*}, \mathrm{sec}$} \\
\hline & & & extra & загальна & \\
\hline 1 & 1970 & \multirow{2}{*}{1.11} & 7 & 18 & \multirow{2}{*}{43} \\
\hline 2 & 1780 & & 8 & 19 & \\
\hline
\end{tabular}

Thus, we get the following: the proposed durations of traffic light cycles are slightly longer than in the fixed-time mode, but under existing algorithms, with the advent of tramcars, the duration of cycles increases until they leave the intersection. Also, the disadvantage of this adaptive algorithm is an early termination of the green signal for the secondary direction with the advent of tram cars. 
Traffic simulations were performed for three intersections, with the greatest attention paid to intersection No. 2 (Fig. 5), as traffic conditions significantly affect vehicle delays along the main direction A-B-A and adjacent streets. The models take into account three types of light control (Table 5), and the research was conducted by changing the traffic intensity on the approaches to the intersection and determining the average and maximum queue lengths.

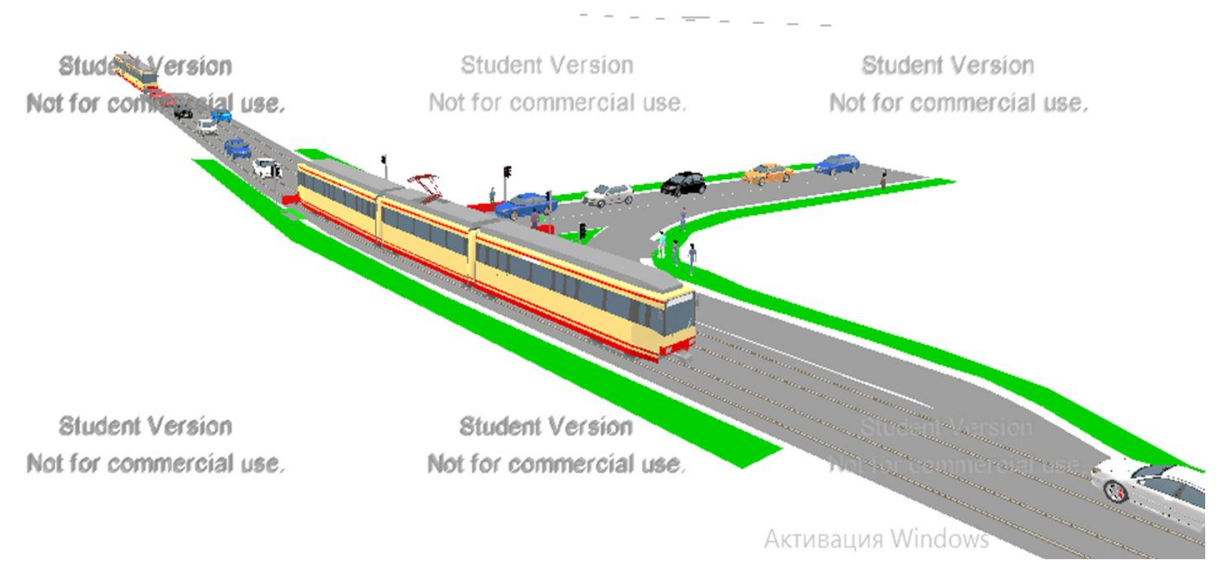

Fig. 5. Picture of the intersection in the Vissim software environment

Table 5

Proposed types of signal controll at intersections

\begin{tabular}{|c|c|c|c|}
\hline Intersection & 1 & 2 & 3 \\
\hline Type & Fixed-time & Adaptive & Adaptive \\
\hline Adaptation type & - & Phase interruption & Main time prolongation \\
\hline $\begin{array}{c}\text { Basis for adaptation } \\
\text { parameters calculating }\end{array}$ & - & Regular uncorrected & Regular corrected \\
\hline
\end{tabular}

It should be noted that at this time at the intersection No. 1, the second type of traffic signal timing is assigned as well as at the intersection No. 2, and at the intersection No. 3, there is a fixed-time cycle (largely because there is tram traffic in both phases). The results of modeling the average and maximum queue lengths for each intersection are shown in Fig. 6-8.

a)

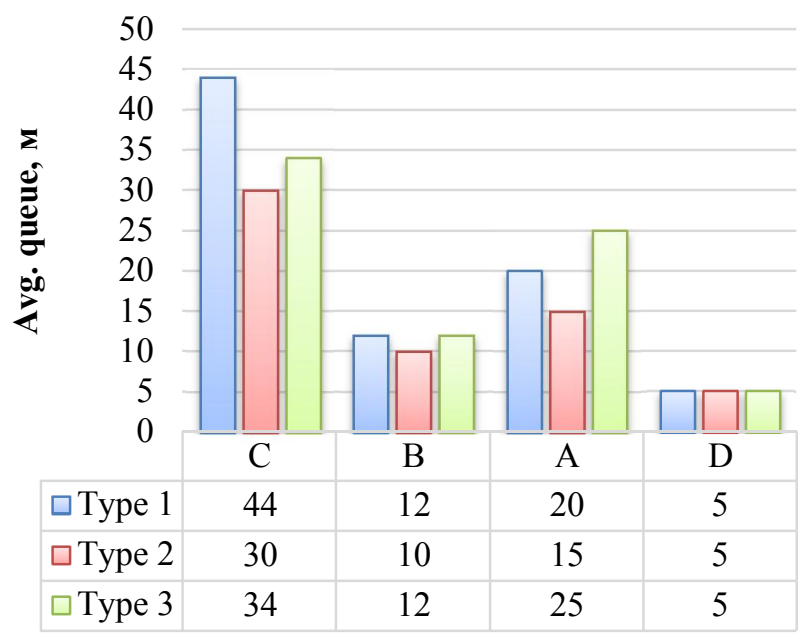

b)

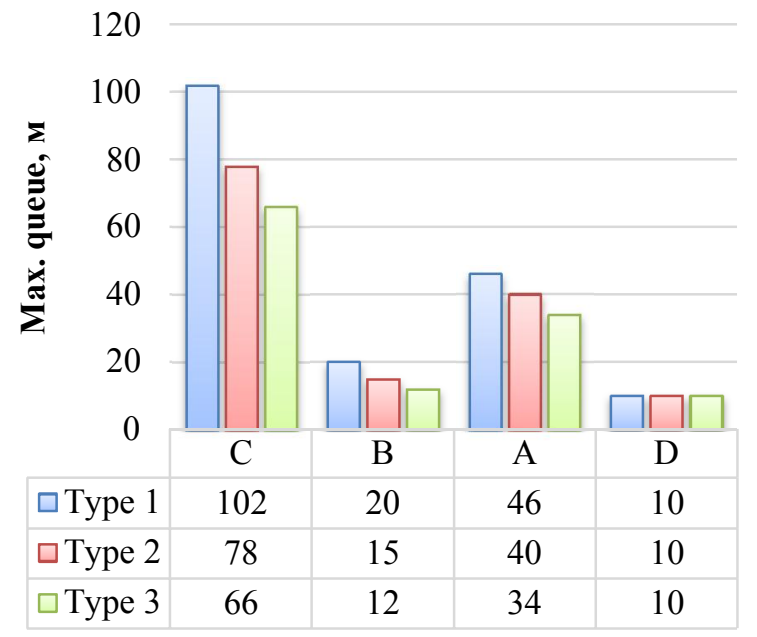

Fig. 6. Results of modeling the average (a) and maximum (b) queue length at the intersection No. 1 
At this intersection, the impact of adaptation on secondary streets is minimal, as the intensity on these approaches is not high, and the difference in queue lengths of $5 \mathrm{~m}$ is within the error, as this distance corresponds to one car. Existing adaptation parameters are suitable for traffic light control at this intersection.

$a$

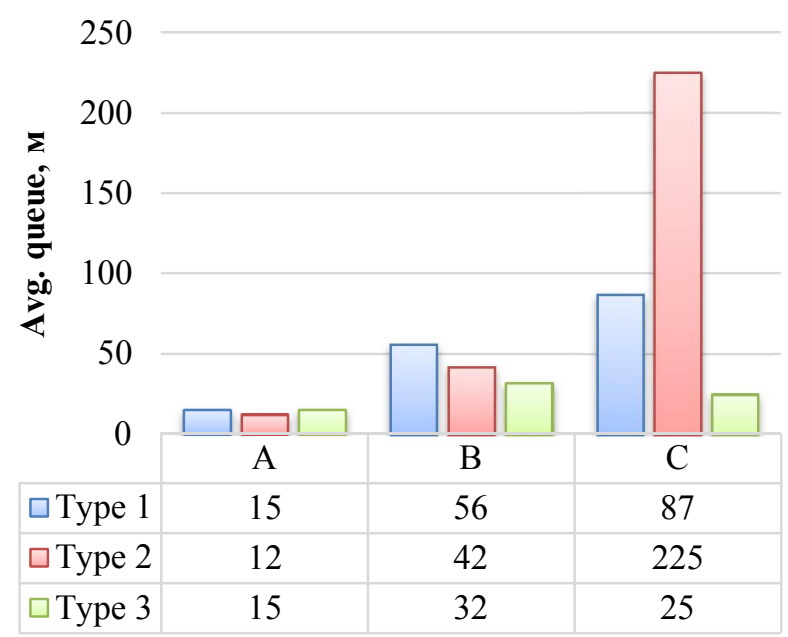

$b$

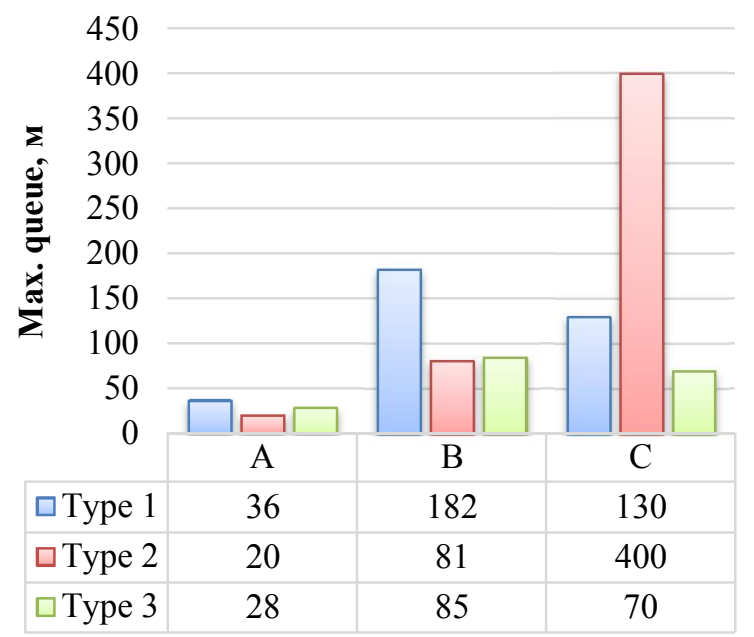

Fig. 7. Results of modeling the average (a) and maximum (b) queue length at the intersection No. 2

The adequacy of the model is confirmed by the values of the queue lengths in the second (existing) type of control, especially in the $\mathrm{C}$ approach where queues for the entire street length are visually observed (402 m).

The results indicate that minimal delays will be observed with the third type of traffic light control.

$a$

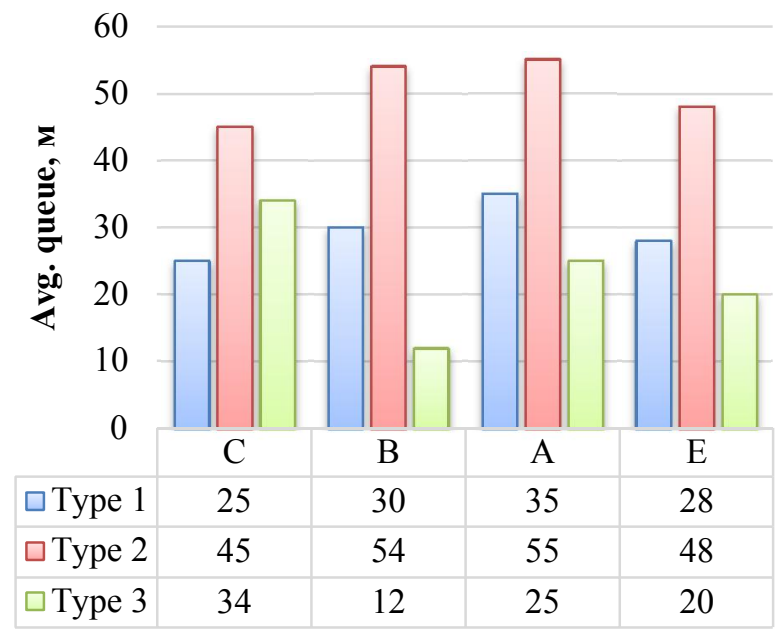

$b$

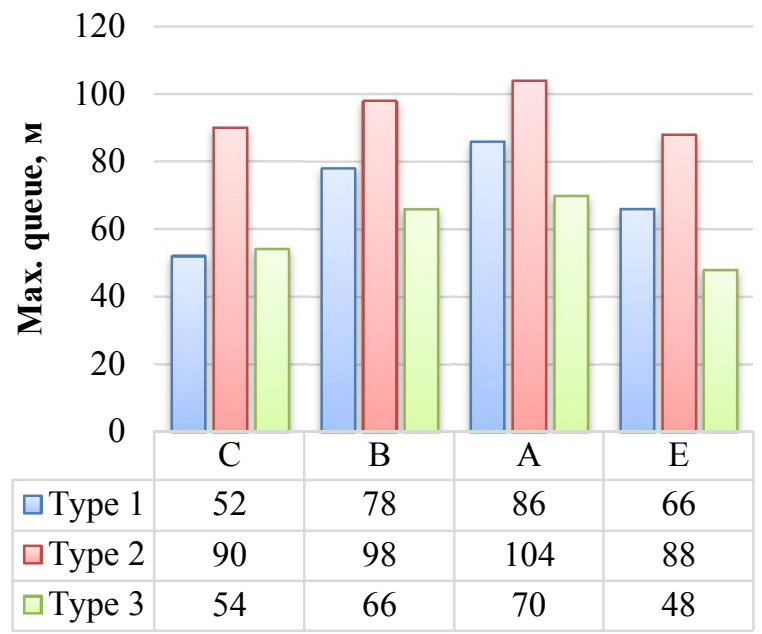

Fig. 8. Results of modeling the average (a) and maximum (b) queue length at the intersection No. 3

At this intersection, the results of the studies are slightly different from the previous ones and indicate that phase interruption adaptation should not be used here. Fewer queues are observed for the third type of control. In the presence of intensive tram traffic from all approaches, there will be an artificial increase in the duration of the traffic light cycle, however, the duration of the main cycle, where traffic is allowed, will be increased in both phases. 
To determine a clear daily schedule for switching traffic light modes, it is necessary to predict the intensity of traffic using the coefficients of daily unevenness (by hours of the day). It is known that when the total traffic intensity at the intersection is less than 600 p.c.u. / h, it is necessary to switch the traffic light objects to the yellow flashing mode signal (YF). The results of calculations of daily traffic intensity are shown in the form of a graph in Fig. 9.

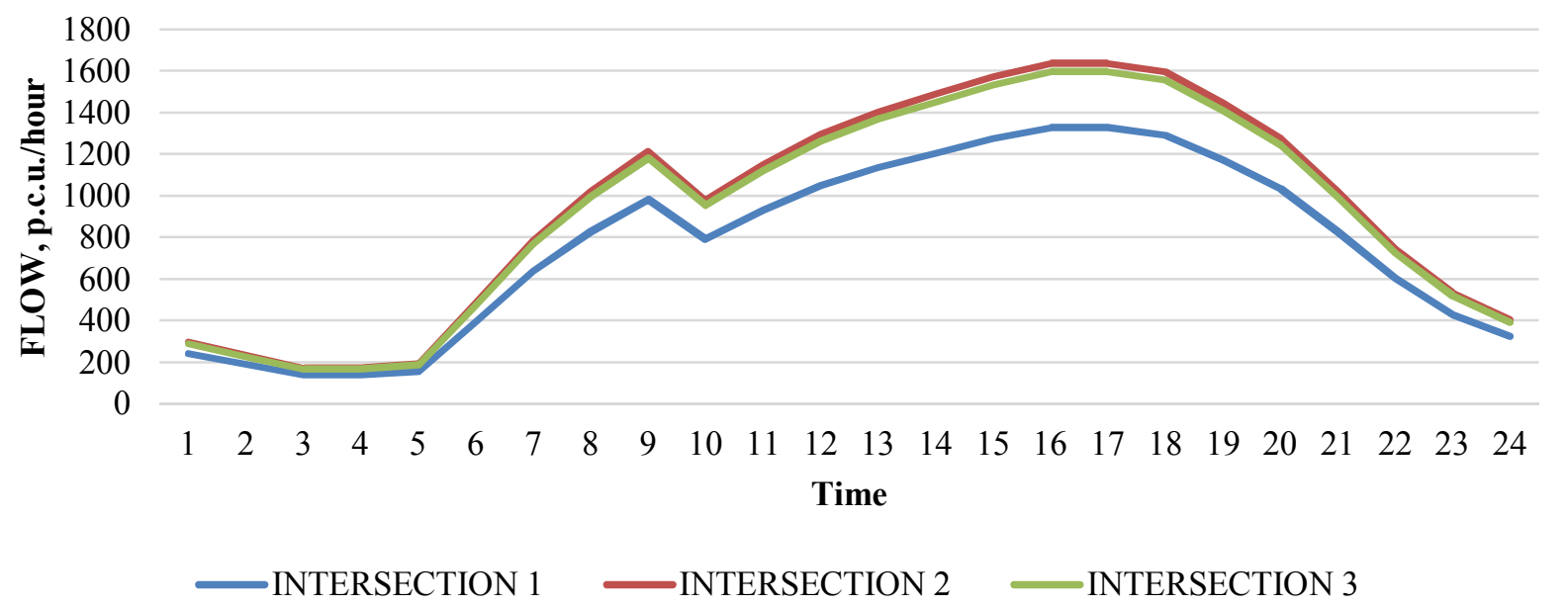

Fig. 9. Forecasting of traffic intensity at intersections during the day

The proposed traffic light signaling modes are shown in Table 6.

Table 6

Recommended changes in traffic lights control

\begin{tabular}{|c|c|c|c|c|c|c|c|}
\hline $\begin{array}{c}\text { Intersection/ } \\
\text { time }\end{array}$ & No. 1 & No. 2 & No. 3 & $\begin{array}{c}\text { Intersection/ } \\
\text { time }\end{array}$ & No. 1 & No. 2 & No. 3 \\
\hline 1 & YF & YF & YF & 13 & Type 2 & Type 3 & Type 3 \\
\hline 2 & YF & YF & YF & 14 & Type 2 & Type 3 & Type 3 \\
\hline 3 & YF & YF & YF & 15 & Type 2 & Type 3 & Type 3 \\
\hline 4 & YF & YF & YF & 16 & Type 2 & Type 3 & Type 3 \\
\hline 5 & YF & YF & YF & 17 & Type 2 & Type 3 & Type 3 \\
\hline 6 & YF & YF & YF & 18 & Type 2 & Type 3 & Type 3 \\
\hline 7 & YF & Type 3 & Tип 3 & 19 & Type 2 & Type 3 & Type 3 \\
\hline 8 & Type 2 & Type 3 & Тип 3 & 20 & Type 2 & Type 3 & Type 3 \\
\hline 9 & Type 2 & Type 3 & Тип 3 & 21 & Type 2 & Type 3 & Type 3 \\
\hline 10 & Type 2 & Type 3 & Тип 3 & 22 & YF & Type 3 & Type 3 \\
\hline 11 & Type 2 & Type 3 & Тип 3 & 23 & YF & YF & YF \\
\hline 12 & Type 2 & Type 3 & Тип 3 & 24 & YF & YF & YF \\
\hline
\end{tabular}

These switching modes provide minimization of traffic delays at intersections.

\section{CONCLUSIONS AND RESEARCH PERSPECTIVES}

The research is aimed to determine the most effective modes of traffic light signaling at signalized intersections using simulations, taking into account public transport priorities.

Time-based priority giving methods are analyzed, as the presence of dense buildings in the sections of the road network does not allow to ensure spatial priorities.

Three adjacent signalized intersections, where the system of giving the priority to public transport operates, have been selected for research. Hourly traffic intensities at intersections with the arterial street of district significance have been determined. The most intense flows are observed at 
intersections No. 2 and No. 3. The magnitude of the peak traffic intensities there can be 500 and more cars/hour depending on the time of day.

A fixed-time traffic light signaling system for signalized intersections is calculated. The duration of the cycle is from 28 to $34 \mathrm{~s}$. However, such calculations do not quite correctly take into account tram traffic, they are rather the basis for the introduction of adaptive algorithms for prioritizing public transport.

For each intersection, the traffic control mode is investigated and offered, considering tram motion. It is recommended to leave the existing design algorithm at the first intersection. On the second and third intersections we recommend to implement algorithms that provide an extra duration of the main cycles by 6-8 s with the advent of tram cars. It is proved that for each separate signalized intersection, there is an optimal mode of traffic light operation with public transport priority. Thus, with certain difficulties in the configuration of some nodes (sections of ascents in front of intersections, large distances to stop lines, etc.), the delay in the secondary direction can become critical. In this case, it is recommended to review the adaptive algorithms of traffic lights and with the help of simulation to choose the one for which the total delays of all vehicles at the intersection will be minimal.

\section{References}

1. Black, J. (2018). Urban transport planning: Theory and practice (Vol. 4). Routledge. (in English).

2. Haitao, H., Yang, K., Liang, H., Menendez, M., \& Guler, S. I. (2019). Providing public transport priority in the perimeter of urban networks: A bimodal strategy. Transportation Research Part C: Emerging Technologies, Volume 107, 171-192. doi: 10.1016/j.trc.2019.08.004 (in English).

3. Zubachyk, R. M. (2015). Improving methods of providing priority traffic for shuttle buses on the city's road network. Candidate's thesis. Kyiv: NTU (in Ukrainian).

4. Scheffler, R., \& Strehler, M. (2017). Optimizing traffic signal settings for public transport priority. In 17th Workshop on Algorithmic Approaches for Transportation Modelling, Optimization, and Systems (ATMOS 2017). Schloss Dagstuhl-Leibniz-Zentrum fuer Informatik. (in English).

5. Dadashzadeh, N., \& Ergun, M. (2018). Spatial bus priority schemes, implementation challenges and needs: an overview and directions for future studies. Public Transport, 10(3), 545-570. (in English).

6. Truong, L. T., Currie, G., Wallace, M., \& De Gruyter, C. (2017). Analytical approach to estimate delay reduction associated with bus priority measures. IEEE Intelligent Transportation Systems Magazine, 9(4), 91-101. (in English).

7. Seredynski, M., Laskaris, G., \& Viti, F. (2019). Analysis of cooperative bus priority at traffic signals. IEEE Transactions on Intelligent Transportation Systems, 21(5), 1929-1940. (in English).

8. Postranskyy, T., Boikiv, M., Afonin, M., \& Rogalskyi, R. (2020). Selection of a Traffic Management Scheme at an Intersection Taking Into Consideration the Traffic Flow Composition. Eastern-European Journal of Enterprise Technologies, 1(3), 103. doi: 10.15587/1729-4061.2020.195327 (in English).

9. Yevchuk, Y., \& Vilshanetska, K. (2017). Evaluation of the introduction of public transport movement priority on the regulated crossroad. Proceedings from VII International youth science forum «litteris et artibus». (pp. 279-280). Lviv: Publishing House of Lviv Polytechnic National University (in English).

10. Azlan, N. N. N., \& Rohani, M. M. (2018). Overview of application of traffic simulation model. In MATEC Web of Conferences (Vol. 150, p. 03006). EDP Sciences (in English).

11. Shaker, H., \& Bigdeli Rad, H. (2018). Evaluation and Simulation of New Roundabouts Traffic Parameters by Aimsun Software. Journal of Civil Engineering and Materials Application, 2(3), 146-158 (in English).

12. Yu, M., \& Fan, W. D. (2017). Calibration of microscopic traffic simulation models using metaheuristic algorithms. International Journal of Transportation Science and Technology, 6(1), 63-77 (in English).

13. Abdelghaffar, H. M., Yang, H., \& Rakha, H. A. (2017). Isolated traffic signal control using Nash bargaining optimization. Global Journal of Research In Engineering (in English).

14. Lopez, P. A., Behrisch, M., Bieker-Walz, L., Erdmann, J., Flötteröd, Y. P., Hilbrich, R., \& et al. (2018). Microscopic traffic simulation using SUMO. In 201821 st International Conference on Intelligent Transportation Systems (ITSC) (pp. 2575-2582). IEEE (in English).

15. Ramadhan, S. A., Joelianto, E., \& Sutarto, H. Y. (2019). Simulation of Traffic Control Using Vissim-COM Interface. Internetworking Indonesia Journal, 11(1), 55-61. (in English).

Received 23.02.2021; Accepted in revised form 08.04.2021. 


\title{
ОБГРУНТУВАННЯ РЕЖИМУ РОБОТИ СВІТЛОФОРНОЇ

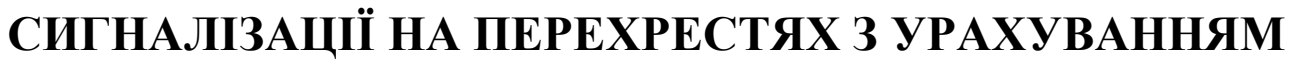 ПРІОРИТЕТУ ГРОМАДСЬКОГО ТРАНСПОРТУ
}

\begin{abstract}
Анотація. Зі зростанням автомобільного парку та збільшенням площі міських агломерацій наявність приватного транспорту на вулицях міст з населенням понад 500 тис. жителів почала відчутно впливати на їхнє життєве забезпечення. Розроблені раніше генеральні плани таких населених пунктів у сучасних реаліях неможливо реалізувати як з фінансового погляду, так і в аспекті організації міського простору. У цих умовах задовольнити потреби користувачів приватних автомобілів неможливо, на перше місие у пріоритетах міської мобільності виходить громадський транспорт. Проблемними ділянками вулично-дорожньої мережі багатьох західноукраӥнських міст є такі, які пролягають у щільній забудові. У зв'язку з цим не завжди є можливість перепланування елементів ділянок вулиць чи перехресть, тому вдосконалення організації дорожнього руху може обмежуватись лише організачійними заходами. Серед них найпопулярнішим та найменш витратним є зміна режимів світлофорного регулювання на перехрестях. Завдяки сучасним можливостям, технічним засобам та науковим досягненням пропускна здатність регульованих перехресть доволі висока. Це ж стосується і приниипів надання пріоритету громадському транспорту на регульованих перехрестях. У результаті досліджень визначено зміну черг перед стоп-лініями перехресть залежно від типів регулювання. Виявлено, що використовуваний тип регулювання спричиняе значні затримки в русі на другорядних вуличях. В результаті дослідження запропоновано використовувати адаптивне регулювання, яке передбачає коригування світлофорного ичиклу. Використання засобів моделювання руху дало можливість вибирати різні режими роботи світлофорної сигналізачії на перехрестях, де передбачено забезпечення пріоритету громадського транспорту, з мінімізацією негативного впливу на прилеглі елементи вулично-дорожньої мережі.
\end{abstract}

Ключові слова: організачія дорожнього руху, пріоритет громадського транспорту, світлофорна сигналізачія, черги перед перехрестями, моделювання руху. 